Journal of Social Sciences 5(4): 261-270, 2009

ISSN 1549-3652

(C) 2009 Science Publications

\title{
The Effect of Contextual Learning in Civic Education on Students' Civic Competence
}

\author{
Kokom Komalasari \\ Faculty of Social Science Education, Indonesia University of Education, Indonesia
}

\begin{abstract}
Problem statement: Globalization demands civic education to develop civic competence involving civic knowledge, civic skills and civic disposition, which are multidimensional. Civic education learning oriented to "contextualized multiple intelligences" concept opened the view of the needs to manage more creative, active participation, meaningful and pleasant learning. This research aimed to describe the effects of contextual learning on civic education of Junior High School students' civic competence. Specifically, this research aimed at examining and finding the influence of the application of contextual teaching and learning component in civic education involving the concept applications of interrelationship, direct experience, application, cooperation, self-regulation and authentic assessment towards citizenship competence of Junior High School students. Approach: Both quantitative and qualitative approaches were adapted in this study. A survey was used as the Quantitative approach and for the in-depth understanding, interviews were used as the qualitative approach. The population of this research was students from Junior High School in West Java Indonesia. Sample was chosen by using cluster, proportional and systematic random samplings and 1004 Junior High School students were involved. Results: The survey showed that contextual learning in civic education influenced positively and significantly and contributed $26 \%$ to the civic competence of Junior High School students. The highest contribution given by applying of cooperation concept (21\%) and self-regulating concept (20\%). Conclusion: It was suggested that contextual teaching and learning in civic education significantly influenced civic competence, the concepts of cooperation and self-regulation were the important factors of civic competence, because they were in accordance with the socio-cultural values. The implications of these findings showed that contextual teaching and learning in civic education was the essence of value education.
\end{abstract}

Key words: Contextual learning, civic education, civic competence

\section{INTRODUCTION}

The development of civic education could not be isolated from globalization, which has an effect on students' life. Globalization demands civic education to develop civic competence involving civic knowledge, civic skills and civic disposition, which are multidimensional. Civic education has also carried out civic education mission for democracy and value-based education. Civic education learning oriented to "contextualized multiple intelligences" concept opened the view of the needs to manage more creative, active participation, meaningful and pleasant learning. Therefore, the implementation of contextual teaching and learning in civic education learning is needed.

The fact that Indonesia today is still dominated by conventional system, so that the implementation of learning oriented to "contextualized multiple intelligences" concept was far from its hope. It was proved with some serious problems faced, in which most students could not relate what they have learnt with the knowledge in recent and future life. It means that learning was not meaningful for students to solve civic problems occurring in their lives. Learning had not been able to develop civic knowledge, civic skills and civic disposition comprehensively. It happened because civic education did not correlate the materials with the students' life reality, was not contextual, gave more abilities to memorize, but not to think creatively, critically and analytically, moreover it caused the students' apathetic attitude and they thought that civic education was not an important and interesting subject.

Therefore, contextual teaching and learning approach should be developed as one of the alternatives. This approach is effective because it assumes that learning process would be actually occurring if the students could find meaningful correlation between abstract thinking and practical application in the real world context. In such learning experience, facts, concepts, principles and procedures as subject materials 
that are internalized through discovery, reinforcement, interrelationship and integrity processes ${ }^{[9,15]}$. Contextual learning is a coordination between subject materials (contents) and intellectual skills that should be possessed by the students in a condition or situation which is suitable with the students' cognitive psychology and environmental needs ${ }^{[2]}$. Furthermore, Johnson ${ }^{[13]}$ emphasized that Contextual Teaching and Learning (CTL) helps the students to see the meaning in academic materials they have learnt by relating the academic subjects with their daily life context, such as their own personal, social and cultural conditions.

This contextual learning approach was assumed to be able to improve the students' competence, thus competence-based curriculum of Junior High School in its learning approach strictly emphasized contextual learning. Therefore, Pelatihan Terintegrasi Berbasis Kompetensi (PTBK) or competence-based integrated training containing the materials of contextual learning for Junior High School teachers should be carried out. This training program was administered by Direktorat Pendidikan Lanjutan Pertama Dirjen Pendidikan Menengah dan Dasar Depdiknas RI in 2004-2005. A necessity to apply this contextual learning was followed in 2006 Curriculum, which was the development of competence-based curriculum.

This situation has encouraged the writer to conduct a study focusing on the effect of contextual learning in civic education on civic competence of Junior High School students in West Java taught by civic education teachers who had followed PTBK. The problems that could be identified are: (1) how the condition of civic education based on civic competence and contextual of Junior High School students in West Java was (2) whether the factors of contextual-based civic education learning have influenced the improvement of Junior High School Students' civic competence in West Java.

Based on the background of the problem about the importance of contextual learning in fostering civic competence, the formulation of problem that could be stated is as follows: "The effects of contextual learning in civic education on Junior High School students' civic competence".

Based on the above formulation of problem, the following problems could be identified: Is there any significant effect of contextual learning in civic education in applying the concepts of relating, experiencing, applying, cooperating, self-regulating, authentic assessment simultaneously on Junior High School students' civic competence?

\section{Literature review:}

Contextual learning: Blanchard ${ }^{[2]}$, Bern and Erickson $^{[1]}$ define that contextual learning is a teaching and learning concept that helps teachers to relate the materials taught with the real world situation and encourages the students to make correlation between their existing knowledge and its application in their lives as the members of family, society and the nation. Therefore, contextual learning enables the students to relate the material content with daily life context to discover the meaning ${ }^{[13]}$.

The characteristics of contextual learning as stated by Blanchard ${ }^{[2]}$ included: (1) relies on spatial memory, (2) typically integrated multiple subjects (3) value of information is based on individual need (4) relates information with prior knowledge and (5) authentic assessment through practical application or solving of realistic problem. Whereas Bern and Erickson ${ }^{[1]}$ stated: (a) interdisciplinary learning; (b) problem-based learning and (c) external contexts for learning. Johnson $^{[14]}$ comprehensively identified eight components, as follows: (a) making meaningful connections (b) doing significant work (c) selfregulated learning (d) collaborating (e) critical and creative thinking (f) nurturing the individual (g) reaching high standards and (h) using authentic assessment. Meanwhile, Sounders ${ }^{[21]}$ focused on REACT (Relating: Learning in life experience context; Experiencing: Learning in searching and discovering context; Applying: Learning when knowledge introduced in the usage context; Cooperating: Learning through interpersonal communication and sharing context; Transferring; learning the use of knowledge in a new situation or context.

Contextual learning in civic education is based on constructivism philosophy assuming that knowledge is a result of human construction. Humans construct their knowledge through their interaction with object, phenomenon, experience and environment. Knowledge is accepted to be true if knowledge could be useful in facing and solving the appropriate problem or phenomenon $^{[10]}$. Contextual learning in civic education is developed based on some learning theories, such as Piaget's cognitive development ${ }^{[17]}$, Bruner's free discovery learning theory ${ }^{[5]}$, Ausubel's meaningful learning and Vygotsky's genetic law of development and zone of proximal development ${ }^{[24]}$.

Contextual learning according to Bern and Erickson $^{[1]}$ could be implemented through five approaches such as: (1) problem-based learning (2) cooperative learning (3) project-based learning (4) Service learning and (5) work-based learning. In civic education, some contextual-based teaching and learning were the developed portfolio of "We the People...Project Citizen" from the Center for Civic Education, program of "Law in a Free Society Series, 
Foundations of Democracy" by the Center for Civic Education. The other alternative model was the developed model of "Exercise in Participation" program. This learning package was designed to develop (participatory skills).

Civic competence: Civic competence is knowledge, value and attitude and the students' competence supports them to be participative and responsible citizens in societal and national lives. Branson ${ }^{[4]}$ emphasized that the intention of civic education is to inculcate qualified and responsible participation in political dan societal living, both in local and national levels. Such participation requires the following civic competence: (1) the mastery of specific knowledge and comprehension (2) the development of intellectual and participatory competence (3) the development of certain mental attitude and character and (4) the true commitment of constitutional democratic fundamental principle and value. The National Standards for Civics and Government (Center for Civic Education) ${ }^{[6]}$ formulated the main components of civic education that are the intention of civic education involving civic knowledge, civic skills and civic disposition.

Civic knowledge is a substance material that should be known by citizens which is related to their rights and obligations as a citizen. This knowledge is the basic of political system and structure, ideal government and social system as documented in national life, universal values in democratic community and cooperating ways to realize common development and living together peacefully in global community.

Based on the National Standards and Civics Framework for the 1988 National Assessment of Educational Progress (NAEP) in Branson ${ }^{[3]}$, these components of civic education were reflected in five important questions such as: (1) What are the political, governmental and civic lives (2) What is the political system foundation (3) How did the government established by the constitution to realize the intention, values and principles of democracy (4) what is the relationship between a nation and other nations and its position in international matters (5) what is the role of in citizen in democracy?

Civic knowledge contains citizenship knowledge based on political, law and civic disciplines. Therefore, civic education presents facts, concepts, generalizations and theories developed from political, law and civic disciplines. Citizenship education should consider the key concepts that were developed further in generalizations and theories. The key concepts that are the essential elements of citizenship education ${ }^{[18]}$ are as follows: (1) democracy and Autocracy (2) cooperation and conflict (3) equality and Diversity (4) justice, the rule of law, rules, laws and human rights (5) Freedom and order (6) individual and community (7) power and authority (8) rights and responsibility. Meanwhile, in 2006 curriculum, the key concepts that should be developed through citizenship education included unity and integrity, norm, power and politics, democracy and political system, 'Pancasila' and globalization.

Civic skill is a skill that develops civic knowledge in order to make the gained knowledge become meaningful because it could be used in facing national and societal life problems. Civic Skills include intellectual skills and participation skills. Intellectual skills are the most important in constructing a wideknowledged, effective and responsible citizens who possess critical thinking skills. The National Standards for Civics and Government and The Civics Framework for 1988 National Assessment of Educational Progress (NAEP) stressed that critical thinking skills include skills to identify, describe, explain, analyze, evaluate, decide and defend the opinion related to public problems. While participation skills include skills to interact, observe and influence.

Civic skills dimension was developed to give knowledge and skills needed to participate effectively in community; participation experience was designed to reinforce the awareness to have skills and superior achievement of the students and to develop the understanding about the importance of active participation among citizens. To participate actively, it requires knowledge about fundamental concepts, history, issues and actual events and facts related to substance and skills to apply the knowledge contextually and the tendency to take actions appropriate with the disposition of the citizens ${ }^{[20]}$.

Quigley, Buchanan dan Bahmueller ${ }^{[20]}$ formulated civic education as thinking habit and attitude of citizen that support the development of sound social function and public interest guaranteed by the democracy system. Conceptually, civic disposition includes a number or personal characteristics such as: "Civic consciousness (respect and civil discourse), individual responsibility, self-discipline, civic-mindedness, openmindedness (openness, skepticism, recognition of ambiguity), compromise (principles of conflict, compassion, generosity and loyalty to the nation and its principles". In other words, courtesy includes human respect and interaction, individual responsibility, selfdiscipline, caring about community, open-mindedness involving openness, skepticism, recognition of ambiguity, compromise attitude involving principles of conflict, compassion, generosity and loyalty to the nation and its principles. 
Branson $^{[4]}$ emphasized that civic disposition implies public or private character that is important in maintaining and developing constitutional democracy. Civic disposition is similar to the civic skills developed slowly due to the effect of what had been learned and experienced by a person at home, school, community and civil society organizations. Personal characteristics such as moral responsibility, self-discipline and the respect of human prestige and dignity from each individual are compulsory. Public characteristics are important as well. The awareness as citizen, courtesy, obeying the rule of law, critical thinking and willing to listen, negotiate and compromise are the characters needed to make democracy run smoothly.

\section{MATERIALS AND METHODS}

This research used two approaches; quantitative and qualitative with the dominant-less dominant design from Creswell ${ }^{[8]}$. The first part of this research used quantitative approach, which was through survey method. The next part used additional (subdominant) paradigm using qualitative approach for in-depth understanding. At this level, interview technique was added.

The population of this research was the ninth-grade students in West Java taught by civic education teachers who had undergone Pelatihan Terintegrasi Berbasis Kompetensi (PTBK) or Competence-Based Integrated Training program in 2004, consisting of 93 Junior High Schools in 26 districts/cities in West Java. The sample was determined by using sampling cluster technique, proportional and systematic random sampling, to obtain 1004 student samples.

The research instrument used was SSHA (Survey of Study Habits and Attitudes) scale from Brown and Holtzman that had been matched with Indonesian Cultural Environment to measure contextual learning variables. Whereas to measure civic competence, variables were accommodated by Civics Assessment Database from the US National Center for Learning and Citizenship (NCLC) in 2006 of civic education subject $^{[16]}$. To measure civic competence variables, multiple choice, rating scale and Likert scale were used in the test. Apart from that, an interview was used on 16 teachers of civic education subject to support and enrich the research analysis besides the questionnaire.

Analysis technique used included descriptive analysis technique to give descriptions of each variable $\mathrm{X}$ and $\mathrm{Y}$, analysis used by group categorization based on score comparison of respondent with ideal score. Hypothetical testing of correlation among variables of this research was done through simple, partial and compound correlation testing using Pearson
Correlations analysis technique. Hypothetical testing of effect was done by enter and stepwise method, multiple regression analysis and contribution with determinacy coefficient analysis.

\section{RESULTS}

Results of descriptive research: The results of descriptive research on the variables of contextual learning in civic education presented that most of contextual learning condition of civic education in West Java were included in average category with $87.22 \%$, moreover $11.67 \%$ belonged to high category and only $1.11 \%$ belonged to low category. Therefore, it could be concluded that most of Junior High Schools in West Java were quite good in applying contextual approach on civic education learning. Among the variables of contextual learning, cooperating concept was the highest applied in civic education learning, followed by self-regulating and relating concepts. The concepts that were still low in application were experiencing, applying and authentic assessment concepts. It could be seen in the Table 1 and 2.

Based on Table 3, the Junior High School students' civic competence, it showed that Junior High School students in West Java had higher civic competence by $81.39 \%$, the rest $18.61 \%$ belonged to average category and there was no low category.

Table 1: Perception of research subject on the contextual learning condition of civic education in west java junior high schools

The Application of contextual approach

\begin{tabular}{lcc} 
in civic education learning & Frequency $(\mathrm{N})$ & Percentage \\
\hline Low & 11 & 1.11 \\
Average & 867 & 87.22 \\
High & 116 & 11.67 \\
\hline Total & 994 & 100.00 \\
\hline
\end{tabular}

Table 2: The perception of research subject on the contextual learning condition of civic education for each research aspect $(\mathrm{N}=994)$

\begin{tabular}{lllr}
\hline & \multicolumn{2}{l}{ Percentage based on category } \\
\cline { 2 - 3 } The variables of contextual & Low & Average & High \\
learning in civic education & 0,70 & 85,21 & 14,08 \\
\hline The application of relating concept & 7,14 & 85,51 & 7,34 \\
The application of experiencing concept & 8,15 & 82,90 & 8,95 \\
The application of applying concept & 0,50 & 70,02 & 29,48 \\
The application of cooperating concept & 2,21 & 77,77 & 20,02 \\
The application of self-regulating concept & 2,11 & 85,8 & 12,08 \\
The application of authentic & & & \\
assessment concept & &
\end{tabular}

Table 3: The civic competence condition of junior high school students in West Java $(\mathrm{N}=994)$

\begin{tabular}{lcc}
\hline Civic competence & Frequency $(\mathrm{N})$ & Percentage \\
\hline Low & 0 & 0,00 \\
Average & 185 & 18,61 \\
High & 809 & 81,39 \\
\hline Total & 994 & 100 \\
\hline
\end{tabular}


Table 4: The civic competence condition of junior high school students in west java for each research aspect $(\mathrm{N}=994)$

\begin{tabular}{llcl}
\hline & \multicolumn{3}{l}{ Percentage based on category } \\
The variables of contextual & -------- \\
learning in civic education & Low & Average & High \\
\hline Civic knowledge & 3,92 & 72,03 & 24,05 \\
Civic skill & 0,00 & 2,01 & 97,99 \\
Civic disposition & 0,00 & 37,83 & 62,17 \\
\hline
\end{tabular}

Table 5: The Result of single (zero order) and compound hypothetic testing

\begin{tabular}{lllllll}
\hline & & & \multicolumn{3}{l}{ Df1 } \\
Model & $\mathrm{R}$ & $\mathrm{R}^{2}$ & Adjusted & $\mathrm{R}^{2}$ & $\mathrm{df2}$ & $\mathrm{p}$-value \\
\hline X123456-Y & $0.51(\mathrm{a})$ & 0.26 & 0.26 & 6 & 987 & 0.00 \\
X1-Y & 0.40 & 0.16 & 0.16 & 1 & 992 & 0.00 \\
X2-Y & 0.41 & 0.17 & 0.17 & 1 & 992 & 0.00 \\
X3-Y & 0.42 & 0.18 & 0.18 & 1 & 992 & 0.00 \\
X4-Y & 0.46 & 0.21 & 0.21 & 1 & 992 & 0.00 \\
X5-Y & 0.44 & 0.20 & 0.20 & 1 & 992 & 0.00 \\
X6-Y & 0.43 & 0.19 & 0.19 & 1 & 992 & 0.00 \\
\hline
\end{tabular}

Thus, it could be concluded that most of Junior High School students in West Java had higher civic competence which showed in Table 4. Among the aspects of Junior High School students' civic competence in West Java, the aspect of civic skills was the highest, in which $97.99 \%$ students had higher category of civic skills. It was followed by the aspect of civic disposition by $62.17 \%$ in which the students had higher civic disposition. While the aspect of civic knowledge was only $24.05 \%$ in which the students belonged to high category and nearly $75 \%$ was in the average category. It could be seen in the Table 4 .

Testing of hypothesis: According to Table 5, based on the result of correlation and regression analysis among $\mathrm{X}(\mathrm{X} 1, \mathrm{X} 2, \mathrm{X} 3, \mathrm{X} 4, \mathrm{X} 5$ and $\mathrm{X} 6)$ and $\mathrm{Y}$ variables in zero order showed that all $\mathrm{X}$ variables, contextual learning in civic education consisting of X1 (the application of relating concept); X2 (the application of experiencing concept); X3 (the application of applying concept), X4 (the application of cooperating concept), X5 (the application of self-regulating concept) and X6 (the application of authentic-assessment concept) had positive, significant correlation with $\mathrm{Y}$ (civic competence). The correlation coefficient of six variables X1-X5 and X6 was $0.40 ; 0.41 ; 0.42 ; 0.46$; 0.44 and 0.43 respectively, with all $\mathrm{p}$ value showed $0.00<0.05$.

The correlation among $\mathrm{X}(\mathrm{X} 1, \mathrm{X} 2, \mathrm{X} 3, \mathrm{X} 4, \mathrm{X} 5$ and $\mathrm{X} 6$ ) and $\mathrm{Y}$ variables showed that $\mathrm{X} 1$ (the application of relating concept); X3 (the application of applying concept), X4 (the application of cooperating concept), X5 (the application of self-regulating concept) had positive, significant correlation with $\mathrm{Y}$ (civic competence). The correlation coefficient of four variables $\mathrm{X} 1, \mathrm{X} 3, \mathrm{X} 4$, dan $\mathrm{X} 5$ was $0.09 ; 0.07 ; 0.10$; 0.12 respectively, with all $\mathrm{p}$ value showed $0.00<0.05$. But for variable $\mathrm{X} 2$ (the application of experiencing concept) and X6 (the application of authentic assessment concept), the positive correlation was not significant with each correlation coefficient 0.03 and 0.05 respectively with $\mathrm{p}$-value for all of them showed $0.00>0.05$. But complexly, the correlation among $\mathrm{X}$ (X1, X2, X3, X4, X5 and X6) and Y variables showed correlation coefficient by 0.51 with $\mathrm{p}$ value for all showed $0.00<0.05$.

Therefore, it could be concluded that in zero order and compound, there was a significant effect of independent X1 (The application of relating concept); X2 (The application of experiencing concept); X3 (The application of applying concept), X4 (the application of cooperating concept), X5 (The application of selfregulating concept) and X6 (The application of authentic-assessment concept) variables on dependent $\mathrm{Y}$ variable (civic competence) but if it was seen partially, variable X2 (The application of experiencing concept) and X6 (The application of authentic assessment concept) did not significantly influence $\mathrm{Y}$ (civic competence)

The analysis of $\mathrm{X}$ variables contribution on the variation of $\mathrm{Y}$ variable complexly could be examined by looking at $\mathrm{R}$ Square value by 0.26 . Based on this data, it could be concluded that the ability of independent variables X1, X2, X3, X4, X5 and X6 to explain the variation of Y dependent variable was $26 \%$, the others were determined by other factors that were not explained in this regression model.

Furthermore, to see the significance of contribution each $\mathrm{X}$ variable had in explaining the factor in $\mathrm{Y}$ values could be seen in the similarity of regression line for standardized value from beta coefficient. Based on the data, the similarity of multiple regression baku could be stated as follows:

$\mathrm{Y}=0.11 \mathrm{X} 1+0.04 \mathrm{X} 2+0.09 \mathrm{X} 3+0.14 \mathrm{X} 4+0.16 \mathrm{X} 5+0.07 \mathrm{X} 6$

Based on the result of regression similarity analysis above, it could be concluded that the change of $\mathrm{Y}$ variable level (civic competence) would be parallel with the change in variables X1 (the application of relating concept); X2 (the application of experiencing concept); X3 (the application of applying concept), X4 (the application of cooperating concept), X5 (the application of self-regulating concept) and X6 (the application of authentic-assessment concept).

Partially, by using multiple regression analysis of stepwise method, it was found that the variable of cooperating concept application contributed the highest 
and most important toward civic competence with $\mathrm{R}$ Square by 0.208 or $21 \%$ if other variables were in constant condition. The next important variable was the application of self-regulating concept by $20 \%$. Then, in simultaneous condition, cooperating and selfregulating contributed 0.23 atau 23\%. Cooperating, relating and experiencing simultaneously contributed by 0.24 or $24 \%$. Cooperating, relating, experiencing and applying simultaneously contributed 0.25 or $25 \%$. Simultaneously, cooperating, relating, applying and self-regulating contributed 0.26 or $26 \%$.

\section{DISCUSSION}

The research finding could be analyzed as follows: First, contextual learning in civic education is natural for students. It means that it motivates the students to act naturally as a human being, which is appropriate with the way our brain functions. Contextual learning stimulates our brain to construct knowledge patterns through interrelationship and reality context of students' lives. In its practice, the theory was partly reflected in Piaget's cognitive development levels, Bruner's free discovery learning theory, Ausubel's meaningful learning, Vygotsky's genetic law of development and zone of proximal.

Second, contextual learning in civic education teaches life principles of citizens. Students are respected as individual being, social being and citizen. As a consequence of that position and nature, students have interdependence, differentiation and selfregulating matter. Those three matters are the principles of contextual learning ${ }^{[13]}$.

Third, contextual learning in civic education supports the creation of democratic learning. It means that civic education learning is the means of democratic learning to develop students to be knowledgeable, responsible and participative democratic citizens. The principles of democracy are included in the content and applied in the process of civic education learning and synergized with habitual and extracurricular activities at school. In contextual learning of civic education as democratic learning, some models summarized by Bern and Erickson ${ }^{[1]}$ were adopted such as: (1) problembased learning (2) cooperative learning (3) projectbased learning and (4) service learning.

Fourth, cooperating and self-regulating have the most important contribution on civic competence. The complex learning tasks such as problem solving, critical thinking and contextual learning actually increased when cooperative strategies were used. Cooperative learning method uses the students' ability to interact. A number of researches showed that in cooperative learning classroom setting, students learnt more from peer-to-peer as peer tutor ${ }^{[22]}$. Therefore, the effective communication skills were developed in this learning model, apart from critical thinking skills, courtesy and respect of difference. Thus, cooperative learning has a positive impact on civic competence.

Contextual learning also developed self-regulated learning according to Zimmerman ${ }^{[25]}$ which was characterized by: (1) students are assumed to have selfawareness of the potential they have and could be used well in the process of self-regulating to reach optimum learning output (2) students have self-orientation toward feedback cycles and reflection during the learning process occurred. In this feedback cycles and reflection, students monitor the effectiveness level of learning method or learning strategy and give responses to reach learning outcome through various ways that are continuously modified ${ }^{[25]}$. Self-regulated learning is a terminology that opens a new context about determinant factors of students' success in learning. The concept of self-regulated learning had changed the focus perspective of learning achievement analysis from students' learning competence or students' learning potential and learning setting at school or home as a fixed entity; now it was changed by the students' readiness to design by themselves learning strategy in improving the learning outcome achievement and their readiness to manage conducive environment for learning.

Fifth, relating and applying was absolutely applied in civic education learning in line with self-identity of civic education. Sixth, experiencing in its implementation was faced with resistance problem toward learning innovation as stated by Quigley ${ }^{[19]}$ that was: Resistance from old generation, including teachers who were maintaining cultural practice and belief and sub culture of authoritarian politic in learning; the slow change of institution at school; not functioning decentralization of decision taking to develop learning design and implementation of curriculum program; resistance toward democratic teaching style and students' enrichment; the lack of training program for civic education teachers to develop civic education classroom as a democratic laboratory and facing with the variation and gap; gap between idea or hope and reality.

Seventh, authentic assessment in its implementation should still be improved because it is faced with the limitations of theoretical skills and authentic assessment practice as stated by Gronlund ${ }^{[11]}$ that although the authentic assessment is very important, based on the field observation result, teachers frequently find it difficult in implementing it because they did not understand the usage procedure. 
From the discussion of research finding, it was found that: First, contextual learning in civic education reflected maximum category of citizenship education in Kerr's concept ${ }^{[14]}$. Because, first, civic education was to thick, inclusive, accommodating various social culture and students' aspiration, involving various societal elements., using formal and non-formal combination, serious but joyful learning situation, emphasizing active participation and interaction of students in and out of the classroom and learning outcome could not be measured by authentic assessment only.

Second, contextual learning in civic education is a process toward education for citizenship in Kerr's concept ${ }^{[14]}$, because by using contextual learning in civic education, students are not only given civic knowledge, but also the way to get that knowledge by the process of constructing knowledge through learning activities while working, active and participative experience at school and community. Thus, contextual learning in civic education does not only develop civic knowledge, such as knowledge and insight of national history, government structure and process and political life, but also civic skills such as critical thinking skill, participatory skill, social skill and civic disposition such as attitude and commitment that are important for the citizenship life through active and participative activities in direct experience at school, home and community. Therefore, through contextual learning in civic education, citizenship education was related to "the whole education experience of students". It was in line with Cogan's concept ${ }^{[7]}$ about citizenship education as following here: “...the more inclusive term encompasses both these in-school experiences as well as out-of-school or non formal/informal learning which takes place in the family, the religious organization, community organizations, the media, which help to shape a holistic citizen". Thus, citizenship education includes learning experience at school and outside school such as family, religious organization, social organization setting, included media and so forth.

Third, contextual learning in civic education discovered the sociocultural value of cooperating in line with the philosophy of "silih asih, silih asah, silih asuh" which meant literally love, teach and care for each other. Therefore, cooperating was a social capital that had been in students' self and should be discovered and optimized in learning.

Fourth, contextual learning in civic education has value education as its core. It is related to basic principle if value education by Harman ${ }^{[12]}$ theoretically stated that "...values is neither taught nor caught, it is learned", which means that the substance of value is not only accepted and taught, but values are processed in the accepted meaning, internalized and standardized as an inherent part of one's personal quality through learning process. Contextual civic education contains value education developed by various approaches formulated by Superka et al. ${ }^{[23]}$, which are: (1) inculcation approach,(2) cognitive moral development approach (3) values analysis approach (4) values clarification approach and (5) action learning approach.

\section{CONCLUSION}

Referring to the proposed research hypothesis, generally the conclusion of this research is that contextual learning in civic education has significant effects on Junior High School students' civic competence. Specifically, the conclusions of this research are: Civic education learning applying the concepts of relating, experiencing, experiencing, applying, cooperating, self-regulating, authentic assessment has significant effect on Junior High School students' civic education.

Based on those conclusions of research hypothetical testing result, a few conclusions could be drawn such as: First, civic education learning has significant effects on Junior High School students' civic competence in West Java. It is due to contextual learning in civic education which applies constructivist learning theory which says that it is natural for students in which civic competence is constructed in individual through continual interaction process between the existing knowledge of students and object, phenomenon, experience and environment

Second, contribution of each contextual learning factor in civic education toward Junior High School students' civic competence in West Java is varied. Among the six factors of contextual learning in civic education, cooperating factor gave the highest contribution, followed by self-regulating, relating and applying factors, while experiencing and authentic assessment factors were not significant.

Third, the application of cooperating and selfregulating concepts in civic education learning were important factors to improve civic competence because they contain the principles of respect toward intact citizen figure as social being and also individual being who has: (1) interdependence principle (2) differentiation principle and (3) self-regulating principle. Those three principles imply the needs of cooperating and independence in the self of students in civic education learning. These cooperating values are sociocultural capital that should be discovered and developed in civic education learning. 
Fourth, the application of relating and applying concepts in civic education learning is an absolute thing because the new paradigm of civic education demands the use of multidiscipline approach, reflects the fact in community; treats the classroom as democratic laboratory; respects the societal contribution in learning and involves the students in community to get civic experience in community.

Fifth, direct experience practiced in civic education learning ideally includes students' activities in exploring, investigating and direct inquiring in field. But in reality, the implementation faced various problems related to teacher's perception on direct experience (applying) concept application in giving relative advantage, compatibility, complexity, triability and observability. Communicating the concepts and direct experience practice had not been optimally done through interpersonal channel or mass media. Not all teachers have similar speed in applying direct experience concept; it is related to difficulty in changing teaching-learning culture. The support of social system members, either school or community, is still low. Therefore, learning innovation should be synergically supported by other component innovation or reformation in educational system.

Sixth, although authentic assessment is very important, it is not optimally done by teachers. The teachers find it difficult in applying the evaluation of civic education because of the complexity of competence that should be evaluated (civic knowledge, civic skills, dan civic disposition). The teachers still have limited knowledge on types, techniques, instruments and procedure of appropriate and accurate evaluation usage procedure to evaluate each competence.

Seventh, contextual learning in civic education had the highest contribution toward civic disposition. It shows that civic education learning has value education as its core. Contextual-based civic education learning contains value education process through learning activities in the classroom as democratic laboratory supported by extracurricular activities as sociopedagogic means to gain hands-on experience and to get involve in service learning in community.

Recommendations: Refer to the conclusions of the research, recommendations were formulated and given to responsible parties in this research.

First, contextual learning in civic education should be developed by teachers at school. In its implementation, in order to make contextual learning at school effective, it requires the following support: (1) government should have strong commitment to improve the quality of education in its entire systems comprehensively and synergically. When the innovation of contextual learning is launched, it should be accompanied by the appropriate availability, the improvement of facility completeness, education fund and teacher training, school-based management development, the improvement of monitoring effort. Supervision and evaluation of learning quality at school (2) national Education Department should cooperate with Lembaga Pendidikan Tenaga Kependidikan (Education Professional Institution) and schools should develop educational system and teaching and learning contextual training program for teachers, followed by classroom practice which is monitored and evaluated and research on the implementation and effect of contextual teaching and learning on the improvement of learning quality (3) the manager of social science education and civic education departments in universities should develop research and development activities of various learning model innovation in order to improve the quality of education. Besides that, it includes involving schools and teachers in lecturing activities, such as field-work practice, field observation, classroom-treatment research, guest lecturer in teaching and learning lecture and so on.

Second, the application of relating concept in civic education learning should be continued and developed by civic education teachers at schools. Teachers could use the form of interdisciplinary approach with variation of structural and functional models and interfiled approach. In implementing the variation of interdisciplinary approach, the teacher should the process of material selection that is essential for the students' lives to be presented in the classroom, such as materials relating to life reality, meeting the students' needs, containing dilemma, controversial in its nature (caused pro-contra). Besides that, the material should be arranged systematically from the specific ones to the complex ones (inductive form).

Third, the application of direct experience concept in civic education learning should be developed further by teachers by reducing the obstacle factors in its implementation, such as the obstacle of conventional teaching and learning culture, the weak teacher's competence in contextual learning method, the lack of support from principle leadership, fund, the support of parents and community, learning facilities and infrastructure and the limitation of time. The application of direct experience could be done by teachers through problem-based learning, inquiry-based learning and structured project-based learning, but in its implementation, to be effective it should consider the following things: (1) the teachers use creatively and 
optimized learning sources and media that are available in students' environment and make the community and its surrounding environment as learning sources (2) the teachers improve theoretical dan practical skills of problem-based learning, inquiry-based learning, structured project-based learning models through education and training programs (3) the students change the passive learning culture (treated teacher as the only source) to be active learning culture (they find their own materials from various sources such as textbook, reference books, magazines, newspaper, government officials and so on (4) parents and community make themselves as learning sources for students and through school committee, they optimize support function for quality learning achievement at schools, such as through participation in providing books, learning instruments and media.

Fourth, the application of applying concept in civic education learning should be continually developed. In its implementation, it needs support from schools in creating conducive civic education learning climate to create the school as democratic laboratory. In this case, schools should develop lesson study model to improve the teachers' competence and also to improve the learning quality. Besides that, schools should develop action learning approach through value habitual program. School should also develop civic-based social service learning through social voluntary labor service and community service. Those activities could be integrated in Organisasi Siswa Intra Sekolah (OSIS) activities and other various extracurricular activities at schools.

Fifth, the application of cooperating concept in civic education learning should develop its implementation through cooperative learning with varied techniques such as jigsaw, number head together, snowball throwing, group investigation, think pair share and many others. In its implementation, the teachers should consider: (1) equal task and responsibility assignments among the group members (2) evaluation and respect toward member (individual) and group (3) students' interaction and communication in (4) individual responsibility of the material handled in cooperative groups (5) variation of group members based on different intelligence, race, nation, ethnic and gender levels (6) skills to facilitate and manage group learning activities.

Sixth, the application of self-regulating concept in civic education learning should develop its implementation through self-regulated learning, in which teachers should give freedom for students to create proactively learning environment and to select learning form and activities based on the students' needs. Portfolio learning model was also applied to develop students' learning activities and creativities.
Seventh, the application of authentic assessment in civic education learning should improve its implementation in technique, instrument and assessment procedure aspects, either performance, attitude, written, project, portfolio and self-assessment. Thus it could measure authentically not only civic knowledge, but the most important are civic skills and civic disposition in the process and outcome of students' learning.

Eighth, this research still has a number of limitations on research method scope, problem focus and research setting: (1) quantitative research method dominating this research could not be explored in-depth and holistically on how the students gave meaning to contextual learning and civic education and what was not uncovered in the surface. For some people, quantitative approach reduced "the depth" of this meaning. For the next research, qualitative approach could be used to develop contextual learning models. Classroom Action Research could be conducted to improve learning quality through contextual learning involving the teacher as the researcher (2) research problem focus, civic education has not been positioned as citizenship education but it is meant as civic education, so that only civic subject setting is studied. While civic competence is a comprehensive aspect that would be more comprehensive result if it was studied related to citizenship education. Therefore, what should be studied further is not only the effect of contextual learning in civic education, but also school climate, student organization, extracurricular activities, habitual program, peer group, family and mass media touch in civic competence (3) research setting has not reached private school sample and has not compared the contribution of contextual learning and civic competence based on geographic location, urban-rural, mountainbeach and West Java administrative regions that obviously have various sociocultural contexts that are quite interesting to study. Therefore, further research could use case-study method to study the implementation of contextual learning and its contribution toward Junior High School students' civic competence based on certain sociocultural context and regional position.

\section{REFERENCES}

1. Berns, R.G. and P.M. Erickson, 2001. Contextual teaching and learning: Preparing students for the new economy. The Highlight Zone: Research @ Work No. 5. http://www.eric.ed.gov/ERICWebPortal/custom/po rtlets/recordDetails/detailmini.jsp?_nfpb=true\&_\& ERICExtSearch_SearchValue_0=ED452376\&ERI CExtSearch_SearchType_0=no\&accno=ED45237 
2. Blanchard, A., 2001. Contextual teaching and learning. Educational services, horizons electronic lesson plans resource. http://coe.csusb.edu/scarcella/helpr.pdf

3. Branson, M.S. and C.N. Quigley, 1998. The Role of Civic Education. Center for Civic Education, Calabasas, pp: 46. http://books.google.com.pk/books?id=22zEGwAA CAAJ\&dq=The+Role+of+Civic+Education

4. Branson, M.S., 1999. Making the case for civic education: Where we stand at the end of the 20th Century. CCE, Washington DC. http://www.civiced.org/papers/articles_mb_june99. html

5. Bruner, J., 1977. The Process of Education. Harvard University Press, Cambridge, ISBN: 10: 0674710010, pp: 97.

6. Center for Civic Education, 1991. Civitas: A Framework for Civic Education, 1st Edn., Calabasas, CA, ISBN: 10: 0898181240, pp: 537.

7. Cogan, J.J., P. Morris and M. Print, 2002. Civic Education in the Asia-Pacific Region: Case Studies across Six Societies. 1st Edn., Routledge Falmer, United States, ISBN: 10: 0415932130, pp: 224.

8. Creswell, J.W., 1994. Research Design: Qualitative and Quantitative Approaches. Sage Publications, London, ISBN: 10: 0803952554, pp: 248.

9. Forgarty, R., 1991. How to Integrate the Curricula: The Mindful School. Hawker Brownlow Education, Illinois, ISBN: 1864011564, pp: 88.

10. Glasserfeld, E., 1996. Introduction: Aspects of Constructivism In: Constructivism: Theory, Perspectives and Practice, Fosnot, C.T. (Ed.). Teachers College Press, New York, ISBN: 0807734888, pp: 7.

11. Gronlund, N.E., 1985. Measurement and Evaluation in Teaching. 5th Rev Edn., Macmillan, New York, ISBN: 0029461901, pp: 576.

12. Harman, G., 1998. Explaining Value and Other Essays in Moral Philosophy, Oxford University Press, USA., ISBN: 10: 0198238045, pp: 138.

13. Johnson, E.B., 2001. Contextual Teaching and Learning: What it is and Why it is Here to Stay. 1st Edn., Corwin Press, Inc., California USA., ISBN: 10: 0761978658, pp: 208.

14. Kerr, D., 1999. Citizenship education: An international comparison. National Foundation for Educational Research (NFER), London. http://inca.org.uk/pdf/citizenship_no_intro.pdf

15. Mathews, B.J. and P. Cleary, 1993. Integrated Curriculum in Use: Practical Ideas for Planning and Assessment. Ashton Scholastic Pty Limited, Melbourne, ISBN: 1863880585, pp: 102.
16. National Center for Learning and Citizenship (NCLC), 2007. Resources to assess student civic competencies and school climate. http://www.ecs.org/ecsmain.asp?page=Qna/splash_ new.asp

17. Piaget, J., 1951. The Child's Conception of the World. National Book Network, Maryland, pp: 397.

http://www.proprofs.com/certification/comptia/aplus/amzn/shop.php?c=books\&n=1000\&i=B0007 H7H9I\&a=buy\&m=All\&p=1

18. Qualifications and Curriculum Authority (QCA), 1998. Education for citizenship and the teaching of democracy in schools. Department of Education and Employment, London. http://www.qcda.gov.uk/libraryAssets/media/6123 _crick_report_1998.pdf

19. Quigley, C.N., 2000. Global trends in civic education. Center for Civic Education, Bandung. http://www.civiced.org/papers/articles_indonesia.html

20. Quigley, C.N. and C.F. Bahmueller, 1991. Civitas: A Framework for Civic Education. 1st Edn., Center for Civic Education, Calabasas, ISBN: 10: 0898181240, pp: 665.

21. Sounders, J., 1999. Contextually based learning: Fad or proven practice. http://www.aypf.org/forumbriefs/1999/fb070999.htm

22. Marx, G., 2005. A programmatic evaluation of civitas: An international civic education exchange program 2004-2005. Center for Civic Education, California, USA. http://www.civiced.org/pdfs/research/CIVEXREP ORTSUMMARYREPORT1205.pdf

23. Superka, D.P., C. Ahrens, J.E. Hedstrom, L.J. Ford and P.L. Johnson, 1976. Values Education Sourcebook: Conceptual Approaches, Materials Analyses and an Annotated Bibliography. Social Science Education Consortium, Inc., Colorado, pp: 262.

http://www.eric.ed.gov/ERICWebPortal/custom/po rtlets/recordDetails/detailmini.jsp?_nfpb=true\&_\& ERICExtSearch_SearchValue_0=ED118465\&ERI CExtSearch_SearchType_0=no\&accno=ED118465

24. Vygotsky, L.S., M. Cole, V. John-Steiner, S. Scribner and E. Souberman, 1978. Mind in Society: Development of Higher Psychological Processes. 14th Edn., Harvard University Press, Cambridge, ISBN: 10: 0674576292, pp: 159.

25. Zimmerman, B.J. and D.H. Schunk, 1989. Selfregulated Learning and Academic Achievement: Theory, Research and Practice. Spring-Verlag Inc., London, ISBN: 10: 0387969349, pp: 212. 